\title{
Copepod predation on phagotrophic ciliates in Oregon coastal waters
}

\author{
Lynne Fessenden, Timothy J. Cowles \\ College of Oceanic and Atmospheric Sciences, Oceanography Admin. Bldg 104, Oregon State University, \\ Corvallis, Oregon 97331-5503, USA
}

\begin{abstract}
Clearance rates on natural assemblages of aloricate, phagotrophic ciliates (20 to $100 \mu \mathrm{m})$ were measured for calanoid copepods in Oregon, USA, coastal waters. Experiments were conducted prior to and throughout the 1991 upwelling season in an effort to determine the trophic significance of ciliates as copepod prey in a system often dominated by large phytoplankton. Copepods cleared ciliates at higher rates than they cleared phytoplankton, except during upwelling-induced diatom blooms. Clearance rates on ciliates ( $\mathrm{ml}$ copepod ${ }^{-1} \mathrm{~h}^{-1}$ ) were measured for Calanus pacificus (12.6 to 32.4), Pseudocalanus sp. (4.8 to 7.4) and Centropages abdominalis (1.2 to 7.1). The highest clearance rates on ciliates were measured when the phytoplankton standing stock was $<5 \mu \mathrm{g} \mathrm{chl} \mathrm{al^{-1 }}$ No detectable clearance of ciliates was measured for Acartia longiremis or C. pacificus during upwelling bloom events $\left(45 \mu \mathrm{g} \mathrm{chl} \mathrm{a}^{-1}\right)$. Ciliate biomass ranged from 3 to $32 \mu \mathrm{g} \mathrm{Cl}^{-1}$ and was significantly less than phytoplankton biomass (100 to $2200 \mathrm{\mu g} \mathrm{C} \mathrm{l}^{-1}$ ) on all dates. During non-upwelling months and between diatom blooms, ciliates contributed 16 to $100 \%$ of the estimated carbon ingested by copepods. Calculated ingestion of ciliate carbon ( $\mu \mathrm{g} \mathrm{C}$ copepod $\left.{ }^{-1} \mathrm{~d}^{-1}\right)$ averaged $6.5( \pm 2.4)$ for $C$. pacificus, $4.6( \pm 1.1)$ for Pseudocalanus sp. and $0.7( \pm 0.4)$ for $C$. abdominalis. Ingestion of ciliates alone provided enough carbon to meet the basic respiration requirements of C. pacificus and Pseudocalanus sp. in January and February respectively. Estimates of predation, based on average copepod densities, indicate 25 to $45 \%$ of the phagotrophic ciliate population is cleared from surface waters per day.
\end{abstract}

KEY WORDS: Microzooplankton · Copepod diet · Upwelling

\section{INTRODUCTION}

Phagotrophic protists are now recognized as a trophic link between $<5 \mu \mathrm{m}$ cells (bacteria, picophytoplankton and nanoflagellates) and metazoans such as copepods (Sherr \& Sherr 1988, Stoecker \& Capuzzo 1990, Gifford 1991). Bactivory by phagotrophic protists has been well documented (reviewed by Sherr \& Sherr 1989), and the quantitative importance of protists as consumers of phytoplankton may equal or exceed that of metazoan grazers (Sherr \& Sherr 1992). S. Neuer \& T. J. Cowles (unpubl.) recently measured protist herbivory in the upwelling region off the Oregon, USA, coast and found that the protist assemblage of heterotrophic and mixotrophic ciliates, and heterotrophic dinoflagellates and nanoflagellates grazed 26 to $50 \%$ of the potential primary production. The ultimate fate of the primary production grazed by protists depends on whether the protists themselves are eaten by higher consumers. Due to the small size of their fecal material (Stoecker 1984, Gowing \& Silver 1985), protists contribute to the recycling and increased residence time of organic matter within surface waters (Welschmeyer \& Lorenzen 1985). It is not clear if the protist-copepod trophic link operates under the diatom bloom conditions typical of coastal upwelling regions. Determining the magnitude of this link in productive coastal waters is relevant not only to trophic studies but also to the quantification of carbon flux.

Phagotrophic protists, including heterotrophic nanoflagellates, heterotrophic dinoflagellates, and heterotrophic and mixotrophic ciliates, often dominate marine nano- ( 2 to $20 \mu \mathrm{m}$ ) and microplankton (20 to $200 \mu \mathrm{m}$ ) assemblages (Sherr et al. 1986, Stoecker \& Capuzzo 1990. Gifford 1991). The $C: N$ ratio of the heterotrophic forms $(3-5: 1)$ is lower than that of phytoplankton $(6-15: 1)$, 
suggesting that protists are a protein-rich prey source for zooplankton predators (reviewed by Stoecker \& Capuzzo 1990). Kleppel et al. (1991) have found the variability in egg production of copepods in the field (coastal and open ocean) to be better correlated with changes in microzooplankton biomass than with diatom biomass. They argue that protists may be responsible for providing a major portion of copepod nutrition, especially that associated with reproductive energy. In the lab, the calanoid copepod Acartia tonsa increases its egg production by as much as $25 \%$ when tintinnid ciliates are included in its diet (Stoecker \& Egloff 1987).

Aloricate, choreotrichous ciliates are commonly the dominant phagotrophic protists in the size range most efficiently grazed by adult copepods (Sherr et al. 1986, Berggreen et al. 1988). Several laboratory studies have demonstrated predation by calanoid copepods on both loricate and aloricate ciliates (Robertson 1983, Ayukai 1987, Jonsson \& Tiselius 1990). When offered a ciliate/ phytoplankton mixture, copepod clearance rates are found to be significantly higher on ciliates (Stoecker \& Sanders 1985, Stoecker \& Egloff 1987, Wiadnyana \& Rassoulzadegan 1989). Recent studies of copepods feeding on natural microplankton assemblages, from estuarine to oceanic waters, suggest ciliates supply from 1 to $80 \%$ of total carbon ingested (Tiselius 1989, Dolan 1991, Gifford \& Dagg 1991, Gifford 1993a). Generally, a greater percentage of ingested carbon is supplied by ciliates when phytoplankton stocks are low or dominated by small cells. Kleppel et al. (1988) found phagotrophic protist carbon (detected by the presence of specific carotenoid pigments) dominated gut contents of copepods off southern California, USA, when phytoplankton biomass and productivity were relatively low.

This paper presents results from a series of copepod grazing experiments conducted with natural microplankton assemblages from Oregon coastal waters between January and August of 1991. We found that calanoid copepods grazed phagotrophic, aloricate ciliates on most sampling dates, those exceptions occurring in late July and August during upwelling-induced diatom blooms. The highest copepod clearance rates on ciliates were measured when the phytoplankton standing stock was $<5 \mu \mathrm{g} \mathrm{chl} \mathrm{a} \mathrm{l}^{-1}$, which was the case during the winter months and between upwelling blooms. The results suggest that the degree of trophic linking between protists and copepods in these waters may vary as a function of timing and intensity of upwelling events.

\section{METHODS}

Copepods and microplankton assemblages were collected 5 miles off Yaquina Head, Oregon, in $70 \mathrm{~m}$ of water. The station is within the upwelling zone on the Newport Hydrographic line $\left(44^{\circ} 40^{\prime} \mathrm{N}\right)$, and was chosen for its historical record of hydrographic and zooplankton population data. Sampling cruises were conducted monthly during January, February, April and June to August of 1991 (twice in July). Copepods were collected in gentle oblique tows from $40 \mathrm{~m}$ with a $0.75 \mathrm{~m}$ ring net of $335 \mu \mathrm{m}$ mesh and a $4 \mathrm{l}$ cod end. Water for the grazing experiments was collected from $8 \mathrm{~m}$ in Niskin bottles with interior silicon springs. This depth was commonly within the chlorophyll and primary productivity maxima, and was the depth from which water was obtained for protistan herbivory experiments conducted on the same dates (Neuer \& Cowles unpubl.). The microplankton assemblage was collected by gently filtering water through a submerged $200 \mu \mathrm{m}$ mesh to remove macrozooplankton. The filtrate was stored in a water bath under a neutral density screen during transport to the shore-based laboratory. A $200 \mathrm{ml}$ aliquot was preserved with $10 \%$ (v/v) acid Lugols solution for microzooplankton enumeration. Samples for in situ chlorophyll analysis were sizefractioned in the lab, collected on GF/F filters, and extracted in $90 \%$ acetone for $24 \mathrm{~h}$ at $0^{\circ} \mathrm{C}$. Temperature and salinity were recorded using a portable CTD.

Copepod clearance rates were determined by measuring the change in chlorophyll concentration and ciliate density during bottle incubations (Gifford 1993b). Copepods were kept in a cooler and sorted under a dissecting scope immediately upon returning to the lab. The most abundant calanoid copepod, > $335 \mu \mathrm{m}$, was chosen for the grazing experiment on each sampling date. Adult females or copepodite stage CVs were placed in $1 \mathrm{l}$ beakers containing the microplankton assemblage, kept in the dark at $10^{\circ} \mathrm{C}$, and allowed to acclimate for $24 \mathrm{~h}$ prior to experimental incubations. As the counting variation typically encountered when enumerating protists is $20 \%$, it is necessary to separate the copepod feeding signal from the variation (Gifford 1993b). Therefore, body size and known phytoplankton clearance rates of the copepod species selected for each experiment were taken into consideration when determining how many copepods to add to the experimental bottles (10 to 25 copepods bottle ${ }^{-1}$ ).

The microplankton assemblage was kept in the dark at $10^{\circ} \mathrm{C}$ for $24 \mathrm{~h}$ while copepods acclimated, and at the start of an experiment was mixed gently and siphoned into 21 polycarbonate bottles using silicon tubing. Three control (microplankton assemblage only) and 3 or 4 experimental (microplankton assemblage plus copepods) bottles were filled along with 1 initial assemblage' bottle. Aliquots for chlorophyll analysis were taken immediately from the 'initial assemblage' bottle, size-fractioned, collected on GF/Fs, and extracted in $90 \%$ acetone. A $200 \mathrm{ml}$ sample (preserved in 
$10 \%$ acid Lugols solution) was also taken from the initial assemblage for enumeration of ciliates. As treatment bottles were not sampled until the end of an experiment, they were free of air space or bubbles which are a known cause of protist mortality (Gifford 1993b). The bottles were secured to a plankton wheel rotating at $0.3 \mathrm{rpm}$. Experimental incubations were conducted at $10^{\circ} \mathrm{C}$ (range of in situ temperature at $8 \mathrm{~m}$ : 8 to $11^{\circ} \mathrm{C}$ ). The winter and spring experiments were incubated for $8 \mathrm{~h}$, at night, in the dark. The summer incubations ran for $12 \mathrm{~h}$ (evening and night) and were exposed to the local light regime, resulting in $7 \mathrm{~h}$ of darkness and $5 \mathrm{~h}$ of light $(100 \mu \mathrm{E})$.

At the end of the experiments, chlorophyll samples were taken in triplicate from each bottle, filtered onto GF/F filters, and extracted in $90 \%$ acetone. Chlorophyll and phaeopigment were analyzed using a Turner Designs Model-10 fluorometer (Strickland \& Parsons 1972). Microzooplankton samples were collected from all bottles and preserved in Lugols solution (as above). Preserved microzooplankton were concentrated by

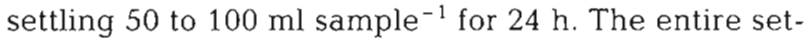
tling chamber was enumerated for all ciliates $>10 \mu \mathrm{m}$ using an inverted microscope at $200 \times$ magnification. A minimum of 100 aloricate, phagotrophic ciliates was counted for each replicate. Assuming the ciliate distribution in the sample is Poisson, confidence intervals can be obtained for single counts (Lund et al. 1958, Venrick 1978). A count of 100 cells will give a $95 \%$ confidence interval of the estimate within $\pm 20 \%$ of the mean (Lund et al. 1958).

Ciliates were measured and categorized by geometrical shape in order to convert to biovolume, and identified to genus when possible. Five to ten size categories were used for each of 2 shapes: spheres and cones. Aloricate ciliate carbon was estimated using the ratio of $0.19 \mathrm{pg} \mathrm{C} \mu \mathrm{m}^{-3}$ (Putt \& Stoecker 1989). As this relationship was determined for ciliates preserved in $2 \%$ Lugols solution, an additional shrinkage factor of 1.5 was applied to the ciliate biovolumes in these experiments (D. Stoecker pers. comm.). It should be mentioned that the ciliate carbon estimates presented here are conservative, as oral membranelles were not always included in the biovolume estimates. A carbon: chlorophyll ratio of 50:1 was used for estimating phytoplankton biomass. Dickson (1993) measured particulate nitrogen at the same station, on the same dates, and estimated carbon:chlorophyll ratios were 45 to 50 during both the winter and summer of 1991. Landry \& Lorenzen (1989) also used a ratio of 50:1 when calculating zooplankton grazing estimates in Washington, USA, coastal waters.

Copepod clearance rates on phytoplankton (based on chlorophyll) and ciliates were calculated from Frost (1972). Clearance rates were calculated only when the difference in concentration between control and experimental bottles proved significant ( $t$-test, $p<0.05$ ). The observed changes in ciliate density exceeded $20 \%$. This difference is representative of the entire ciliate count (ciliates ranging in size from 10 to $100 \mu \mathrm{m}$ ). Copepod clearance rates on specific size categories of ciliates and chlorophyll were not analyzed in these experiments. The coefficient of variation between replicate chlorophyll samples was $5 \%$. Ingestion rates were calculated by multiplying clearance rate by the initial standing stock (Marin et al. 1986). Ingestion rates calculated in this way will be slightly higher than those calculated using the logarithmic mean prey concentration during a given experiment (Frost 1972).

The Bakun upwelling index (Bakun 1973; made available by the NOAA/NMFS Pacific Fisheries Environmental Group, Monterey, CA, USA) was used as a measure of the strength of the wind-induced coastal upwelling on all sampling dates (Fig. 1). The index, presented as weekly averages at $45^{\circ} \mathrm{N}, 125^{\circ} \mathrm{W}$, has units of $\mathrm{m}^{3} \mathrm{~s}^{-1}$ (100 $\mathrm{m}$ of coastline $)^{-1}$. A positive index indicates water is driven offshore, while a negative index indicates downwelling. Indices $>50$ reflect strong upwelling along this coastline (Small \& Menzies 1981).

\section{RESULTS}

The microplankton assemblage used in the experiments was collected on the same day as the copepods, due to constraints on boat time, and thus sat for $24 \mathrm{~h}$ (in the dark at $10^{\circ} \mathrm{C}$ ), while the copepods were acclimating. The phytoplankton biomass increased on average by $50 \%$ in the absence of large grazers. The increase occurred in both the 3 to $20 \mu \mathrm{m}$ and $>20 \mu \mathrm{m}$ chlorophyll size ranges. The ciliate density increased on average by $43 \%$, but showed little change in size distribution. On the April and late July dates, ciliate mortality occurred in the microplankton assemblage and ciliate density was ca $45 \%$ lower in the experimental assemblage than in the field.

Chlorophyll concentrations ranged from 2 to $45 \mu \mathrm{g}$ $\mathrm{I}^{-1}$ in the experimental microplankton assemblages ( 2 to $33 \mathrm{\mu g} \mathrm{l}^{-1}$ in situ) between January and August of 1991 (Table 1). The late July and August sampling dates coincided with strong upwelling events (Fig. 1). On these dates, chlorophyll concentration in the experimental assemblage was ca $45 \mu \mathrm{g} \mathrm{l}^{-1}$ and more than $80 \%$ of the phytoplankton biomass was composed of diatoms $>20 \mu \mathrm{m}$ (Fig. 2). On all other dates, with the exception of June $\left(11.2 \mu \mathrm{g}\right.$ chl $a^{-1} \mathrm{l}^{-1}$, the chlorophyll concentration was $<5 \mu \mathrm{g} \mathrm{l}^{-1}$. During January, February and early July, the majority of the phytoplankton biomass was in the $<20 \mu \mathrm{m}$ fraction (Fig. 2). 


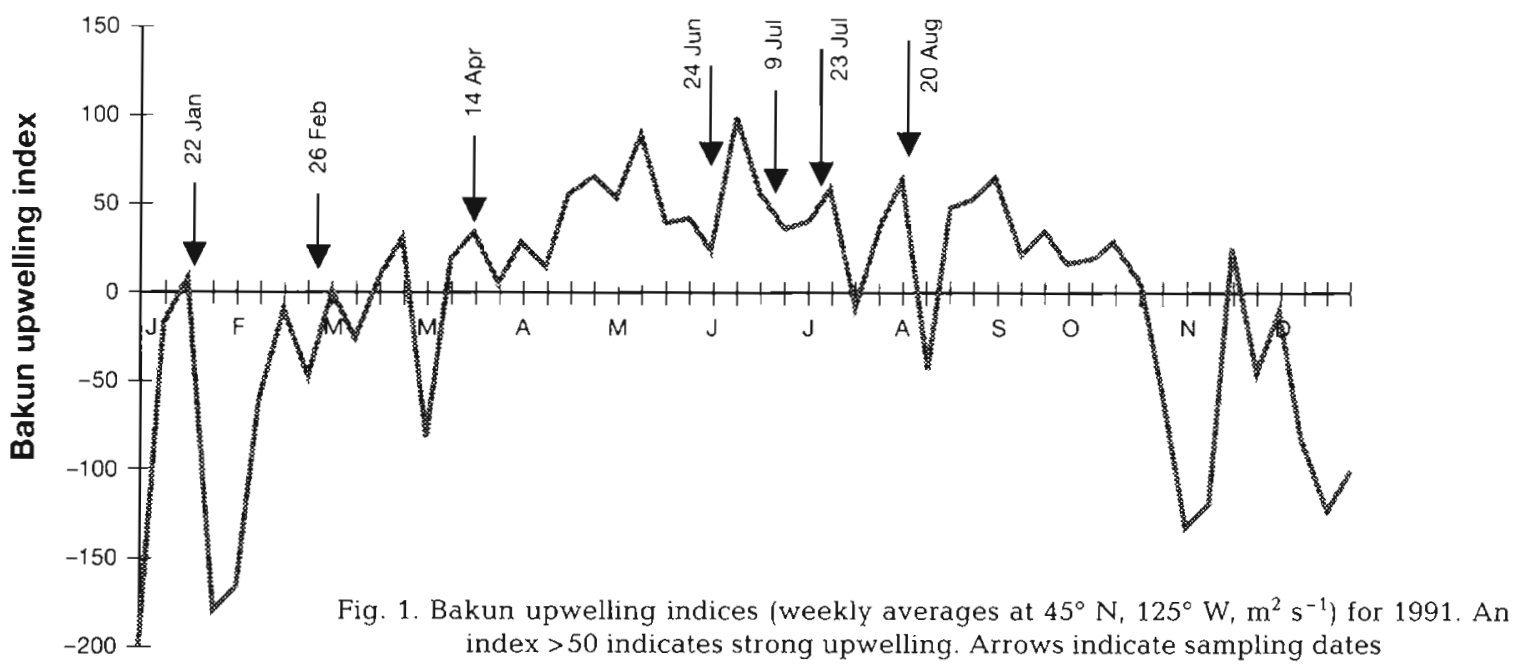

Phagotrophic ciliate carbon was $\ll 10 \%$ of the phytoplankton carbon on all but the February sampling date, when it was $32 \%$. Ciliate densities ranged from 1200 to 7700 cells $1^{-1}$ (1100 to 6500 in situ), with highest abundances in February and during the August upwelling bloom (Table 1). Aloricate choreotrichous genera were most prominent. Tintinnids were present but not abundant $\left(<100 \mathrm{l}^{-1}\right)$. The prominent mixotrophs were Laboea spp. and Tontonia spp., and their contribution to total numbers was greatest in January and February (ca 50\%). No large predatory ciliates, such as Dindinium spp., were observed on any of the sampling dates.

Growth of ciliates in the controls was observed in January, June and late July, and ranged from 8 to $35 \%$ (mean $25 \%$ ). Mortality was observed in the February, April, July and August experiments, ranging from 6 to $46 \%$ (mean $20 \%$ ). There was no apparent response of copepod clearance rates to either mortality or growth of the ciliates (Table 2 ).

Copepods cleared ciliates during the 5 grazing experiments conducted between January and early July, when chlorophyll concentrations did not exceed

Table 1. Initial conditions for copepod grazing experiments conducted in 1991

\begin{tabular}{|crccc|}
\hline Date & $\begin{array}{c}\text { Chl a } \\
\left(\mu \mathrm{g} \mathrm{l}^{-1}\right)\end{array}$ & $\begin{array}{c}\text { Aloricate } \\
\text { ciliates }>10 \mu \mathrm{m} \\
\left.(\text { ind. })^{-1}\right)\end{array}$ & $\begin{array}{c}\text { Phytoplankton } \\
\text { carbon } \\
\left(\mu \mathrm{g} \mathrm{l}^{-1}\right)\end{array}$ & $\begin{array}{c}\text { Ciliate } \\
\text { carbon } \\
\left(\mu \mathrm{g} \mathrm{I}^{-1}\right)\end{array}$ \\
\hline 22 Jan & 3.4 & 4810 & 170 & 11 \\
26 Feb & 2.0 & 7370 & 100 & 32 \\
14 Apr & 4.6 & 1200 & 230 & 3 \\
24 Jun & 11.2 & 1700 & 560 & 3 \\
9 Jul & 4.7 & 2200 & 235 & 6 \\
23 Jul & 44.3 & 3500 & 2215 & 8 \\
20 Aug & 44.6 & 7700 & 2230 & 15 \\
\hline
\end{tabular}

$12 \mu \mathrm{g}^{-1}$ (Table 2). In late July and August, when upwelling events induced diatom bloom conditions $\left(44 \mu \mathrm{g} \mathrm{chl} \mathrm{a} \mathrm{l}^{-1}\right)$, no significant clearance of ciliates was measured.

The highest clearance rates on ciliates were measured for Calanus pacificus in January, 12.6 to $32.4 \mathrm{ml}$ copepod $^{-1} \mathrm{~h}^{-1}$ (Table 2). However, no clearance of phytoplankton by C. pacificus was detected. In February, Pseudocalanus sp. cleared ciliates at rates of

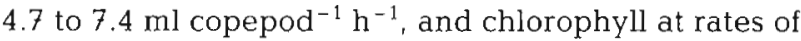
0.8 to $3.5 \mathrm{ml} \mathrm{copepod}^{-1} \mathrm{~h}^{-1}$. Centropages abdominalis was the most abundant mesozooplankton grazer available for experiments in April, June and early July. This copepod cleared aloricate ciliates at rates of 6.3 to $7.1 \mathrm{ml}^{\text {copepod }}{ }^{-1} \mathrm{~h}^{-1}$ in April and early July, and at somewhat lower rates, 1.2 to $3.4 \mathrm{ml} \mathrm{copepod}^{-1}$ $\mathrm{h}^{-1}$, in June. Centropages abdominalis cleared phytoplankton at measurable rates only on the July date $\left(0.4\right.$ to $\left.1.2 \mathrm{ml} \mathrm{copepod}^{-1} \mathrm{~h}^{-1}\right)$. Only 2 replicates are reported for 9 July due to copepod mortality in one of the bottles.

No detectable clearance of ciliates was measured for Acartia longiremis and Calanus pacificus during the diatom blooms in late July and August respectively. Clearance rates based on chlorophyll removal were 0.0 to $0.7 \mathrm{ml} \mathrm{copepod}^{-1} \mathrm{~h}^{-1}$ for $A$. longiremis and 0.3 to $0.9 \mathrm{ml} \mathrm{copepod}^{-1} \mathrm{~h}^{-1}$ for C. pacificus (Table 2).

Ingestion of ciliate carbon, in $\mu \mathrm{g} C$ copepod ${ }^{-1} \mathrm{~d}^{-1}$. averaged $6.5( \pm 2.4)$ for Calanus pacificus, $4.6( \pm 1.1)$ for Pseudocalanus sp. and $0.7( \pm 0.4)$ for Centropages abdominalis (Table 3). The highest weight-specific ingestion rate of ciliates was found for Pseudocalanus spp., which ingested $58 \%$ of its body carbon. This was an order of magnitude higher than the weight-specific ingestion measured for Calanus pacificus $16 \%$ of body carbon) and Centropages abdominalis ( 1 to $7 \%$ body carbon). 


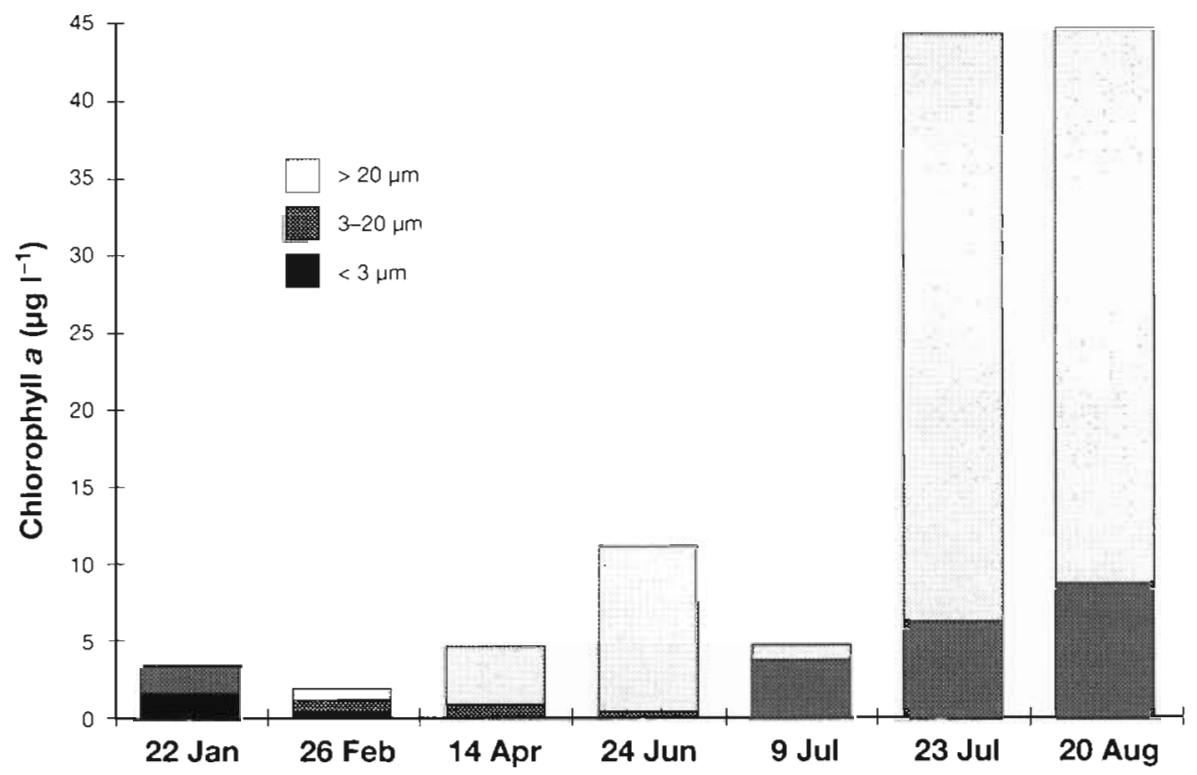

Fig. 2. Initial phytoplankton biomass for grazing experiments conducted in 1991 (in terms of size-fractioned chlorophyll a)

Table 2. Measured and calculated results of copepod grazing experiments conducted in 1991: phytoplankton (in terms of chl a) and ciliate growth rate $(k \pm S D)$, decline rate $(g)$ in the presence of copepods, and copepod clearance rates. All experimental replicates presented. ns: no significant difference between control and experimental prey densities, $p>0.05$

\begin{tabular}{|c|c|c|c|c|c|c|c|}
\hline \multirow[t]{2}{*}{ Date } & \multirow[t]{2}{*}{ Copepod species } & \multicolumn{2}{|c|}{$\begin{array}{c}k \\
\left(h^{-l}\right)\end{array}$} & \multicolumn{2}{|c|}{$\underset{\left(h^{-1}\right)}{g}$} & \multicolumn{2}{|c|}{ 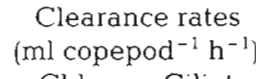 } \\
\hline & & $\mathrm{Chl}$ & Ciliates & Chl & Ciliates & Chl & Ciliates \\
\hline 22 Jan & $\begin{array}{l}\text { Calanus pacificus } \\
\text { (female) }\end{array}$ & $\begin{array}{c}-0.0169 \\
(0.0000)\end{array}$ & $\begin{array}{c}0.0442 \\
(0.0035)\end{array}$ & $\begin{array}{l}\text { ns } \\
\text { ns } \\
\text { ns } \\
\text { ns }\end{array}$ & $\begin{array}{l}0.1318 \\
0.1392 \\
0.0992 \\
0.0541\end{array}$ & $\begin{array}{l}\text { ns } \\
\text { ns } \\
\text { ns } \\
\text { ns }\end{array}$ & $\begin{array}{l}32.4 \\
30.7 \\
23.1 \\
12.6\end{array}$ \\
\hline $26 \mathrm{Feb}$ & $\begin{array}{l}\text { Pseudocalanus sp. } \\
\text { (female) }\end{array}$ & $\begin{array}{c}-0.0239 \\
(0.0055)\end{array}$ & $\begin{array}{l}-0.0248 \\
(0.0260)\end{array}$ & $\begin{array}{l}0.0228 \\
0.0151 \\
0.0052 \\
0.0114\end{array}$ & $\begin{array}{l}0.0312 \\
0.0306 \\
0.0474 \\
0.0461\end{array}$ & $\begin{array}{l}3.5 \\
2.3 \\
0.8 \\
1.8\end{array}$ & $\begin{array}{l}4.8 \\
4.7 \\
7.4 \\
7.2\end{array}$ \\
\hline $14 \mathrm{Apr}$ & $\begin{array}{l}\text { Centropages abdominalis } \\
\text { (female) }\end{array}$ & $\begin{array}{l}-0.0010 \\
(0.0116)\end{array}$ & $\begin{array}{l}-0.0578 \\
(0.0230)\end{array}$ & $\begin{array}{l}\text { ns } \\
\text { ns } \\
\text { ns }\end{array}$ & $\begin{array}{l}0.0459 \\
0.0443 \\
0.0443\end{array}$ & $\begin{array}{l}\text { ns } \\
\text { ns } \\
\text { ns }\end{array}$ & $\begin{array}{l}7.1 \\
6.9 \\
6.9\end{array}$ \\
\hline 24 Jun & $\begin{array}{l}\text { Centropages abdominalis } \\
\text { (female) }\end{array}$ & $\begin{array}{c}0.0096 \\
(0.0015)\end{array}$ & $\begin{array}{c}0.0065 \\
(0.0147)\end{array}$ & $\begin{array}{l}\text { ns } \\
\text { ns } \\
\text { ns }\end{array}$ & $\begin{array}{l}0.0360 \\
0.0250 \\
0.0128\end{array}$ & $\begin{array}{l}\text { ns } \\
\text { ns } \\
\text { ns }\end{array}$ & $\begin{array}{l}3.4 \\
2.3 \\
1.2\end{array}$ \\
\hline $9 \mathrm{Jul}$ & $\begin{array}{l}\text { Centropages abdominalis } \\
\text { (female) }\end{array}$ & $\begin{array}{c}0.0146 \\
(0.0020)\end{array}$ & $\begin{array}{c}-0.0052 \\
(0.0043)\end{array}$ & $\begin{array}{l}0.0033 \\
0.0099\end{array}$ & $\begin{array}{l}0.0542 \\
0.0559\end{array}$ & $\begin{array}{l}0.4 \\
1.2\end{array}$ & $\begin{array}{l}6.3 \\
6.5\end{array}$ \\
\hline $23 \mathrm{Jul}$ & $\begin{array}{l}\text { Acartia longiremis } \\
\text { (female) }\end{array}$ & $\begin{array}{c}0.0238 \\
(0.0006)\end{array}$ & $\begin{array}{c}0.0270 \\
(0.0253)\end{array}$ & $\begin{array}{r}0.0063 \\
0.0035 \\
-0.0002\end{array}$ & $\begin{array}{l}\text { ns } \\
\text { ns } \\
\text { ns }\end{array}$ & $\begin{array}{l}0.7 \\
0.4 \\
0.0\end{array}$ & $\begin{array}{l}\text { ns } \\
\text { ns } \\
\text { ns }\end{array}$ \\
\hline $20 \mathrm{Aug}$ & $\begin{array}{l}\text { Calanus pacificus } \\
\text { (CV) }\end{array}$ & $\begin{array}{c}0.0025 \\
(0.0033)\end{array}$ & $\begin{array}{l}-0.0076 \\
(0.0217)\end{array}$ & $\begin{array}{l}0.0065 \\
0.0065 \\
0.0022\end{array}$ & $\begin{array}{l}\text { ns } \\
\text { ns } \\
\text { ns }\end{array}$ & $\begin{array}{l}0.9 \\
0.9 \\
0.3\end{array}$ & $\begin{array}{l}\text { ns } \\
\text { ns } \\
\text { ns }\end{array}$ \\
\hline
\end{tabular}


Table 3. Copepod ingestion rates $( \pm \mathrm{SD}$ ) on phytoplankton (chl a) and ciliate prey in Oregon coastal waters, total carbon ingested per day, and carbon required for respiration ${ }^{2}$. ns: no significant clearance rate measured, $p=0.005$

\begin{tabular}{|c|c|c|c|c|c|}
\hline \multirow[t]{2}{*}{ Date } & \multirow[t]{2}{*}{ Copepod species } & \multicolumn{2}{|c|}{$\begin{array}{c}\text { Ingestion rates } \\
\left(\mu \mathrm{g} \mathrm{C} \text { copepod } \mathrm{d}^{-1} \mathrm{~d}^{-1}\right)\end{array}$} & \multirow{2}{*}{$\begin{array}{c}\text { Total carbon } \\
\text { ingested } \\
\left(\mu \mathrm{g} \mathrm{C} \text { copepod }{ }^{-1} \mathrm{~d}^{-1}\right)\end{array}$} & \multirow{2}{*}{$\begin{array}{c}\text { Respiration } \\
\text { requirement }^{a} \\
\left(\mu g C \text { copepod }^{-1} d^{-1}\right)\end{array}$} \\
\hline & & $\mathrm{Chla}$ & Ciliates & & \\
\hline 22 Jan & Calanus pacificus & ns & $6.5(2.4)$ & $6.5(2.4)$ & 6.5 \\
\hline 26 Feb & Pseudocalanus sp. & $5.0(2.7)$ & $4.6(1.1)$ & $9.6(1.9)$ & 0.6 \\
\hline $14 \mathrm{Apr}$ & Centropages abdominalis & ns & $0.5(0.01)$ & $0.5(0.01)$ & 1.1 \\
\hline 24 Jun & Centropages abdominalis & ns & $0.2(0.06)$ & $0.2(0.06)$ & 1.1 \\
\hline 9 Jul & Centropages abdominalis & $4.6(3.2)$ & $0.9(0.02)$ & $5.5(3.0)$ & 1.1 \\
\hline $23 \mathrm{Jul}$ & Acartia longiremis & $23.1(16.2)$ & ns & $23.1(16.2)$ & 0.3 \\
\hline 20 Aug & Calanus pacificus & $37.3(18.5)$ & ns & $37.3(18.5)$ & 6.5 \\
\hline \multicolumn{6}{|c|}{${ }^{\partial} R=0.101 W_{\mathrm{c}}{ }^{0884}$ (Dagg et al. 1982) } \\
\hline
\end{tabular}

\section{DISCUSSION}

Omnivory is especially apparent among copepods living in highly dynamic environments which exhibit numerous phytoplankton bloom cycles (Landry 1981). Our results reinforce previous observations of a protistcopepod trophic link being tied into such cycles (Gifford \& Dagg 1991). We found that calanoid copepods in Oregon coastal waters cleared aloricate, phagotrophic ciliates from natural microplankton assemblages at considerably higher rates than they cleared phytoplankton, except during upwelling-induced diatom blooms. During non-upwelling months and between bloom events, ciliates contributed 16 to $100 \%$ of the estimated carbon ingested by copepods, even though ciliate biomass was significantly less than phytoplankton biomass.

Ciliates comprised $100 \%$ of the estimated carbon ingested by Calanus pacificus in January when the entire phytoplankton assemblage was $<20 \mu \mathrm{m}$ in size and about half of it was $<3 \mu \mathrm{m}$ (see Fig, 2). In February, Pseudocalanus sp. averaged $52 \%$ phytoplankton and $48 \%$ ciliate carbon in its daily ration (Table 3 ). The chlorophyll biomass was still low, but diatoms $>20 \mu \mathrm{m}$ accounted for $42 \%$ of it. Pseudocalanus sp. cleared ciliates at rates 1.3 to 9.3 times higher than rates measured for clearance of chlorophyll. On 9 July, $16 \%$ of the carbon ingested by Centropages abdominalis was attributable to ciliates and $84 \%$ to phytoplankton. On that date, $20 \%$ of the chlorophyll biomass was $>20 \mu \mathrm{m}$. C. abdominalis cleared ciliates at rates 5 to 15 times higher than they cleared chlorophyll. Similar results were found for Acartia tonsa in Terrebonne Bay, on the inshore Gulf of Mexico (Gifford \& Dagg 1991). A. tonsa cleared protists at rates an order of magnitude higher than those measured for chlorophyll. Aloricate ciliates dominated the protist population in the Gulf, and they contributed $50 \%$ of the carbon ingested by $A$. tonsa when the chlorophyll standing stock averaged $<5 \mu \mathrm{m}$ in size (August). Ciliates comprised only $2 \%$ of the carbon ingested by $A$. tonsa in January, when the chlorophyll standing stock was dominated by large diatoms $>20 \mu \mathrm{m}$. During both seasons in Terrebonne Bay, the chlorophyll biomass was high $\left( \pm 30 \mu \mathrm{g} \mathrm{l}^{-1}\right)$.

Hign chlorophyll biomass in our experiments was only associated with diatom bloom conditions. In general, ciliates made the largest contribution to copepod diet when large diatoms $(>20 \mu \mathrm{m})$ composed $<50 \%$ of the chlorophyll biomass. These results are consistent with the observed grazing behavior of 3 species of Calanus in open and ice-edge areas of the Greenland Sea (Barthel 1988). In the diatom bloom conditions of the shelf polyna, copepods ingested diatoms, although ciliate biomass was substantial. In pack-ice regions where the phytoplankton was dominated by small flagellates, copepods primarily ate ciliates. In open waters, where diatom and ciliate biomass were roughly equal, copepods ingested both diatoms and ciliates.

We observed an exception to this trend in the April and June experiments, when Centropages abdominalis did not clear chlorophyll at detectable rates even though large diatoms were present. Ingestion of ciliates alone did not meet the estimated respiration requirements (Dagg et al. 1982) of C. abdominalis on these dates (Table 3). Copepods in all other experiments satisfied their respiration requirements with the ingestion of ciliates or phytoplankton or the combination of both. Centropages is known to tend toward carnivory (Paffenhoffer \& Knowles 1980), and it is likely that they were feeding on protists or nauplii that weren't accounted for in these experiments.

Clearance rates on ciliates for Centropages abdominalis ranged from 28 to $170 \mathrm{ml}$ copepod ${ }^{-1} \mathrm{~d}^{-1}$. These rates are in the same range as those measured for $C$. hamatus (32 to $125 \mathrm{ml}$ copepod $\mathrm{d}^{-1} \mathrm{~d}^{-1}$ ) feeding on ciliates in a natural microplankton assemblage in coastal 
Sweden (Tiselius 1989). In June, clearance rates on ciliates for C. abdominalis were much lower $(25$ to $50 \mathrm{ml}$ copepod ${ }^{-1} \mathrm{~d}^{-1}$ ) than those measured in April and early July (150 to $170 \mathrm{ml} \mathrm{copepod}^{-1} \mathrm{~d}^{-1}$ ). The lower clearance rates in June may be due to a shift in the prey size distribution ( $50 \%$ of the ciliates were $<20 \mu \mathrm{m}$ in size). With the exception of June, cell size of the aloricate ciliate populations during all other experiments averaged 30 to $60 \mu \mathrm{m}$.

Copepod clearance rates on dinoflagellates were not determined. Neuer (1992), using epifluorescence microscopy, found heterotrophic gymnodinoid dinoflagellates were more numerous than ciliates in these waters on the same sampling dates. However, ciliate biomass equaled or exceeded the dinoflagellate biomass on all but the August date. Assuming copepods cleared heterotrophic dinoflagellates at the same rate as they cleared ciliates, the additional protist carbon ingested would come close to balancing the respiration requirements of Centropages abdominalis.

Copepod omnivory is to be likely unnecessary during diatom bloom conditions. In contrast to the high clearance rates of Calanus pacificus on ciliates in January, no clearance on ciliates was detected for either C. pacificus or Acartia longiremis during the upwelling-induced diatom blooms in August and late July respectively. Clearance rates on chlorophyll were low for both species (see Table 2), but the chlorophyll biomass was so high $\left(44 \mu \mathrm{g} \mathrm{l^{-1 }}\right)$ that phytoplankton carbon ingested averaged $23 \mu \mathrm{g}$ copepod $^{-1} \mathrm{~d}^{-1}$ for $A$. longiremis (578\% of body carbon) and $37 \mu \mathrm{g}$ copepod $^{-1} \mathrm{~d}^{-1}$ for C. pacificus (33\% of body carbon; Table 3).

It is important to restate that the experimental food concentrations in our study did not exactly replicate field conditions. Because of the $24 \mathrm{~h}$ acclimation period, the experimental microplankton assemblages often had higher concentrations of both ciliates and phytoplankton than the in situ assemblages on the actual sampling dates. The composition of the assemblage was not greatly changed, however, and the increased prey concentrations still fell in the range of what copepods experience in these waters. The largest increase between experimental and in situ phytoplankton biomass occurred during the June experiment $(138 \%)$, but as no clearance rate on phytoplankton for Centropages abdominalis was detected, results were not affected. A complete doubling of the ciliate population occurred between the August sampling and experimental incubation. In this case, no clearance on ciliates was detected for Calanus pacificus so the extreme increase again did not sway experimental results. In the 3 experiments done with Centropages abdominalis, similar clearance rates on ciliates were measured on 2 dates (April and early July) when the ciliate density differed by a factor of 2 (Table 1). Although the prey densities in the incubations differed somewhat from the field, we feel the results can still be safely applied to field conditions.

The presence of predatory ciliates (2 predator-prey systems in the same bottle) and mixotrophic ciliates (counted twice, once as chlorophyll, once as protist) in the natural assemblages could bias the outcome of this type of grazing experiment. We did not observe large predatory ciliate species on any of our sampling dates. Phytoplankton biomass was much greater than ciliate biomass, with the exception of the February date, so that the mixotroph contribution to the total chlorophyll was probably small. In February, however, mixotrophs represented $50 \%$ of the phagotrophic ciliate count (according to epifluorescence counts by Neuer 1992) and as chlorophyll biomass was low, the clearance rates on chlorophyll for Pseudocalanus sp. may be biased by the presence of mixotrophs. The autotrophic ciliate Mesodinium rubrum was also abundant in February (4000 $1^{-1}$; Neuer 1992), and some individuals may have been mistakenly included in the phagotrophic protists counts.

Ciliate densities observed in this study are in the range of those previously reported for coastal waters (Sherr et al. 1986, Burkill et al. 1987, Gifford 1988 , Montagnes et al. 1988, Tiselius 1989), although somewhat lower than the high end of the range (2700 to 27800 ) reported by Landry \& Hassett (1982) in Washington coastal waters. An estimate of copepod predation on ciliate biomass was obtained by applying average clearance rates to historical average abundance estimates of Pseudocalanus spp., Calanus marshallae (assume similar rate to Calanus pacificus), and Centropages abdominalis at the same station (Peterson \& Miller 1976). Ignoring fine-scale vertical differences, and considering only these 3 species, the estimated grazing impact is $25 \%$ of the ciliate population removed per day. This is likely an underestimate, since Acartia clausii and A. longiremis both play a numerically important role in the copepod assemblage at this location during the summer months (Peterson \& Miller 1976). Including them in the estimate would no doubt increase the impact. Also, copepod nauplii are known to consume phagotrophic protists. Dolan (1991) measured clearance rates of $0.4 \mathrm{ml}$ nauplius ${ }^{-1} \mathrm{~h}^{-1}$ for $A$. tonsa nauplii on phagotrophic protists in Chesapeake Bay. Applying this clearance rate to abundance estimates of the feeding stages of copepod nauplii (Peterson \& Miller 1976, Landry \& Lorenzen 1989) adds an additional impact of 10 to $20 \%$ clearance per day on the ciliate population.

Neuer (1992) found that although ciliates and heterotrophic dinoflagellates ingested both phototrophic and heterotrophic prey in Oregon coastal waters in 
1991, gymnodinoid dinoflagellates ingested a greater percentage of phototrophic food sources during upwelling bloom periods, whereas the ciliate impact was on heterotrophic food sources. We are presently working up the results of a second field season in which the contribution of heterotrophic dinoflagellates to copepod diet in these waters is examined.

An altered view of pelagic carbon flux is suggested by the concept of the microbial food web serving as the principal food resource for metazooplankton (Sherr \& Sherr 1988). In productive coastal waters, the consumption of primary production by heterotrophic protists versus rapid sinking of a diatom bloom implies carbon is available in the water column to metazoan consumers, or for remineralization, for a longer period of time. If protists are consuming as much as $50 \%$ of the primary production in neritic waters, the existence of a protist-metazoan link would greatly influence the fate of that carbon. Copepods contribute disproportionately to carbon flux due to the rapid sinking of their fecal pellets. Grazing and sediment trap measurements made in Washington shelf waters show micro-crustaceans contributing up to $21 \%$ of the grazing pressure on phytoplankton, but $65 \%$ of the vertical flux of organic carbon (Landry \& Lorenzen 1989).

There is no evidence for mass sinking of diatom blooms in the Washington and Oregon coastal upwelling system. Landry \& Lorenzen (1989) maintain that the vast majority of Washington shelf production is utilized locally and that up to $50 \%$ is grazed by protists. Neuer \& Cowles (unpubl.) found the protist grazing impact to be of similar magnitude on the Oregon shelf. Our results illustrate the potential for a substantial portion of protist secondary production to be consumed by copepods between diatom bloom events, and therefore to be linked to the carbon flux to deeper water or shelf sediments.

Acknowledgements. Sincere thanks to P. Tiselius, D. Gifford, and D. Stoecker for constructive comments on this manuscript; to D. Gifford for her advice on experimental protocol; to $S$. Neuer and $M$. Dickson for encouragement and inspiration during our team sampling regime; and to the captains of the O.S.U. R/V 'Sacajawea'. Special thanks to M. Lorang for his tireless enthusiasm and superior sea legs. This work was supported by USDE Patricia Roberts Harris Fellowship for Women and Minorities in Science to L.F.

\section{LITERATURE CITED}

Ayukai, T (1987). Predation by Acartia clausi (Copepoda. Calanoida) on two species of tintinnids. Mar. microb. Food Webs 2: 45-52

Bakun, A. (1973). Coastal upwelling indices, west coasts of North America, 1946-71. U.S. Dept Commerce, NOAA Tech. Rep. NMFS-SSRF 471
Barthel, K.-G. (1988). Feeding of three Calanus species on different phytoplankton assemblages in the Greenland Sea. Meeresforsch. 32: 92-106

Berggreen, U., Hansen, B., Kiørboe, T. (1988). Food size spectra, ingestion and growth of the copepod Acartia tonsa during development: implications for determination of copepod production. Mar. Biol. 99: 341-352

Burkill, P. H., Mantoura, R. F. C., Llewellyn, C. A., Owens, N. J. P. (1987). Microzooplankton grazing and selectivity of phytoplankton in coastal waters. Mar. Biol. 93: 581-590

Dagg, M. J., Vidal, J., Whitledge, T. E, Iverson, R. L., Goering, J. J. (1982). The feeding, respiration, and excretion of zooplankton in the Bering Sea during a spring bloom. Deep Sea Res. 29: 45-63

Dickson, M. L. (1994). Nitrogen dynamics in a coastal upwelling regime. Ph.D. thesis, Oregon State University, Corvallis

Dolan, J. R. (1991). Microphagous ciliates in mesohaline Chesapeake Bay waters: estimates of growth rates and consumption by copepods. Mar. Biol. 111: 303-309

Frost, B. W. (1972). Effects of size and concentration of food particles on the feeding behavior of the marine planktonic copepod Calanus pacificus. Limnol. Oceanogr. 17 $805-815$

Gifford, D. J. (1988). Impact of grazing by microzooplankton in the northwest arm of Halifax Harbour, Nova Scotia. Mar. Ecol. Prog. Ser. 47: 249-258

Gifford, D. J. (1991). The protozoa-metazoan trophic link in pelagic ecosystems. J. Protozool. 38: 81-86

Gifford, D. J. (1993a). Protozoa in the diets of Neocalanus spp. in the Oceanic Subarctic Pacific Ocean. Progr. Oceanogr 32: $223-237$

Gifford, D. J. (1993b). Consumption of protozoa by copepods feeding on natural microplankton assemblages. In: Kemp, P. F., Sherr, B. F., Sherr, E. B., Cole, J. J. (eds.) Handbook of methods in aquatic microbial ecology. Lewis Publishers, Boca Raton, p. 723-729

Gifford, D. J., Dagg, M. J. (1991). The microzooplanktonmesozooplankton link: consumption of planktonic protozod by the calanoid copepods Acartia tonsa Dana and Neocalanus plumchrus Murukawa. Mar. microb. Food Webs. 5: 161-177

Gowing, M. M., Silver, M. W. (1985). Minipellets: a new and abundant size class of marine fecal pellets. J. mar. Res. 43 $395-418$

Jonsson, P. R., Tiselius, P. (1990). Feeding behavior, prey detection and capture efficiency of the copepod Acartia tonsa feeding on planktonic ciliates. Mar. Ecol. Prog. Ser. 60: $35-44$

Kleppel, G. S., Frazel, D., Pieper, R. E., Holliday, D. V. (1988). Natural diets of zooplankton off southern California. Mar. Ecol. Prog. Ser. 49: 231-241

Kleppel, G. S., Holliday, D. V., Pieper, R. E. (1991). Trophic interactions between copepods and microplankton: a question about the role of diatoms. Limnol. Oceanogr. 36: $172-178$

Landry, M. R. (1981). Switching between herbivory and carnivory by the planktonic marine copepod Calanus pacificus. Mar. Biol. 65: 77-82

Landry, M. R., Hassett, R. P. (1982). Estimating the grazing impact of marine micro-zooplankton. Mar. Biol. 67 : $283-288$

Landry, M. R., Lorenzen, C. J. (1989). Abundance, distribution, and grazing impact of zooplankton on the Washington shelf. In: Landry, M. R., Hickey, B. M. (eds.) Coastal oceanography of Washington and Oregon. Elsevier, Amsterdam, p. $175-210$ 
Lund J. W. G., Kipling, C., Le Cren, E. D. (1958). The inverted microscope method of estimating algal numbers and the statistical basis of estimations by counting. Hydrobiologia 11: $143-170$

Marin, V., Huntley, M. E., Frost, B. (1986). Measuring feeding rates of pelagic herbivores: analysis of experimental design and methods. Mar. Biol. 93: 49-58

Montagnes, D. J. S., Lynn, D. H., Roff, J. C., Taylor, W. D. (1988). The annual cycle of heterotrophic planktonic ciliates in the waters surrounding the Isles of Shoals, Gulf of Maine: an assessment of their trophic role. Mar. Biol. 99: $21-30$

Neuer, S. (1992). Role of protist grazing in the Oregon Upwelling System. Ph.D. thesis. Oregon State University, Corvallis

Paffenhöfer, G. A., Knowles, S. C. (1980). Omniverousness in marine copepods. J. Plankton Res. 2: 355-365

Peterson, W. T., Miller, C. B. (1976). Zooplankton along the continental shelf off Newport, Oregon, 1969-1972: distribution, abundance, seasonal cycle and year-to-year variations. Publication no. ORESU-T-76-002, Oregon State University Sea Grant College Program, Corvallis

Putt, M., Stoecker, D. K. (1989). An experimentally determined carbon:volume ratio for marine 'oligotrichous' ciliates from estuarine and coastal waters. Limnol. Oceanogr. 34: $1097-1107$

Robertson, J. R. (1983). Predation by estuarine zooplankton on tintinnid ciliates. Estuar. coast. Shelf Sci. 16: 27-36

Sherr, B., Sherr, E. (1989). Trophic impacts phagotrophic protozoa in pelagic food webs. In: Hatton, T., et al. (eds.) Recent advances in microbial ecology. Japan Scientific Societies Press, Tokyo, p. 388-394

Sherr, E., Sherr, B. (1988). Role of microbes in pelagic food webs: a revised concept. Limnol. Oceanogr. 33: $1225-1227$

This article was presented by B. \& E. Sherr (Senior Editorial Advisors), Corvallis, Oregon, USA
Sherr, E., Sherr, B. (1992). Trophic roles of pelagic protists: phagotrophic flagellates as herbivores. Arch. Hydrobiol Beih. Ergebn. Limnol. 37: 165-172

Sherr, E., Sherr, B. F., Paffenhöfer, G. A. (1986). Phagotrophic protozoa as food for metazoans: a 'missing' trophic link in marine pelagic food webs? Mar microb. Food Webs 1 $61-80$

Small, L. F., Menzies, D. W. (1981). Patterns of primary productivity and biomass in a coastal upwelling region. Deep Sea Res. 28: 123-149

Stoecker, D. K. (1984). Particle production by planktonic ciliates. Limnol. Oceanogr. 29: 930-940

Stoecker, D. K., Capuzzo, J. M. (1990). Predation on protozoa: its importance to zooplankton. J. Plankton Res. 12: $891-908$

Stoecker, D. K., Egloff, D. E. (1987). Predation by Acartia tonsa Dana on planktonic ciliates and rotifers. J. exp. mar. Biol. Ecol. 110: 53-68

Stoecker, D. K., Sanders, N. K. (1985). Differential grazing by Acartia tonsa on a dinoflagellate and a tintinnid. J. Plankton Res. 7: 85-100

Strickland, J. H. D., Parsons, T. R. (1972). A practical handbook of seawater analysis, 2nd edn. Bull. Fish. Res. Bd Can. 167: 1-310

Tiselius, P. (1989). Contribution of aloricate ciliates to the diet of Acartia clausi and Centropages hamatus in coastal waters. Mar. Ecol. Prog. Ser. 56: 49-56

Venrick, E. L. (1978). Statistical considerations. In: Sournia, A. (ed.) Phytoplankton manual. UNESCO, Paris, p. 69-74

Welschmeyer, N. A., Lorenzen, C. A. (1985). Pigment budgets: zooplankton grazing and growth in a temperate fjord and the Central Pacific Gyre. Limnol. Oceanogr. 30: 1-21

Wiadnyana, N. N., Rassoulzadegan, F. (1989). Selective feeding of Acartia clausi and Centropages typicus on microzooplankton. Mar. Ecol. Prog. Ser. 53: 37-45

Manuscript first received: August 20, 1993

Revised version accepted: January 18, 1994 